\title{
CYP2D6*6 Allele
}

National Cancer Institute

\section{Source}

National Cancer Institute. CYP2D6*6 Allele. NCI Thesaurus. Code C45622.

Human CYP2D6*6 allele is located in the vicinity of $22 \mathrm{q} 13.1$ and is approximately $4 \mathrm{~kb}$ in length. This allele, a variant form of the CYP2D6 wild-type allele, encodes cytochrome P450 2D6*6 protein. The CYP2D6*6 allele exhibits a single nucleotide deletion (g.1707delT) in exon 3 that results in a frameshift and generates a stop codon located one codon after the deletion. This alteration yields a truncated CYP2D6*6 protein that is enzymatically inactive. 